\title{
Biophysical characterization of 21.5- kDa myelin basic protein (MBP) and the effects of zinc on its structure
}

\section{Danielle K. Lanthier, Kenrick A. Vassall, and George Harauz}

Department of Molecular and Cellular Biology, College of Biological Science, University of Guelph, Guelph, ON Canada. Faculty supervisor: Dr. George Harauz. For correspondence, please email: gharauz@uoguelph.ca.

\begin{abstract}
Myelin Basic Protein (MBP) is a highly abundant protein in central nervous system (CNS) myelin that has a critical role in its proper formation and functioning. The 21.5-kDa isoform of MBP has been shown to be selectively imported into the nucleus of myelin-producing cells, oligodendrocytes, and may be involved in signaling pathways that affect the formation and recovery of CNS myelin. The first step in understanding potential nuclear binding partners of 21.5-kDa MBP is to characterize the structure of the protein. In this study, circular dichroism and fluorescence spectroscopy were used to analyze the structure of 21.5-kDa rmMBP (recombinant murine MBP) in vitro in the presence and absence of $\mathrm{Zn}^{2+}$, an abundant trace metal in CNS myelin that has been suggested to affect MBP structure. Fluorescence spectroscopy with a probe for hydrophobic protein regions showed that $\mathrm{Zn}^{2+}$ may affect the conformation of 21.5-kDa MBP in aqueous solution.
\end{abstract}

Keywords: myelin basic protein (MBP); intrinsically-disordered protein; circular dichroism; fluoresence spectroscopy

\section{Introduction}

The mammalian central nervous system (CNS) is composed of neurons that conduct electrochemical signals between cell groups, and glial cells that support and protect the neurons. Oligodendrocytes, a subset of glial cells, produce projections of lipid-rich membrane that wrap around the neuronal axons at intervals to facilitate rapid saltatory signal conduction between nodes, areas of the axon not insulated by myelin (Yamazaki et al. 2007). Demyelination, the loss of myelin due to damage and degradation, results in the loss of efficient axonal signal conduction and is associated with a number of debilitating diseases, including Multiple Sclerosis (MS), which often result in the loss of motor control and other symptoms (Hanafy et al. 2011).

Myelin basic protein (MBP) is the second most abundant protein associated with CNS myelin, and is the only known structural protein required for myelin formation (Moscarello et al. 1997; Harauz and Boggs 2013). This importance is exemplified in the shiverer mutant mouse, which has a deletion in the $M B P$ gene, and which almost completely lacks compact CNS myelin (Tyszka et al. 2006). MBP is a family of intrinsically-disordered proteins that are encoded by the Gene in the Oligodendrocyte Lineage (Golli) and can be subdivided into classical MBPs and Golli-specific MBPs (Bamm and Harauz 2008). The classical MBPs arise from transcription start site 3 , and differential splicing of a single mRNA transcript produces splice isoforms ranging from 14.0 to $21.5 \mathrm{kDa}$ in mass (Campagnoni and Campagnoni 2008). The most abundant of these isoforms in mature CNS myelin is the highly basic $18.5-\mathrm{kDa}$ isoform, which can be post-translationally modified by processes that include phosphorylation and deimination (or citrullination) (Vassall et al. 2013). This isoform is a peripheral membrane protein that localizes to the cytosolic leaflet of the myelin membrane and attaches it to the opposing cytosolic leaflet, effectively condensing myelin layers around the nerve axon and forming the major dense line (MDL) (Readhead et al. 1990). It has been shown that this protein is also involved in a number of other processes, including cytoskeletal assembly (Boggs et al. 2001; Boggs et al. 2005; Harauz and Boggs 2013; Smith et al. 2012a) and voltage-operated calcium channel modulation (Smith et al. 2011).

Unlike 18.5-kDa MBP, the 21.5-kDa MBP isoform contains exon-II of the Golli gene complex, which encodes 26 amino acid residues (Smith et al. 2012b). Whereas 18.5$\mathrm{kDa}$ MBP has primarily been observed only in the cytoplasm in vivo, 21.5-kDa MBP localizes to the cell nucleus as well as the cytoplasm (Pedraza et al. 1997; Smith et al. 2012a, 2012b, 2013; Harauz and Boggs 2013; Ozgen et al. 2014). Exon-II has been shown to contain a non-traditional nuclear localization signal (Smith et al. 2012b) and contains a higher 
proportion of basic residues than the remainder of the protein (Hill and Harauz 2005). At high cell density in N19oligodendrocyte cell culture, 21.5-kDa MBP was shown to translocate out of the nucleus, indicating that 21.5-kDa MBP may be involved in cell proliferation signaling and regulatory pathways (Smith et al. 2013).

The over-expression of 21.5-kDa MBP has been shown to activate multiple kinases that are suggested to have involvement in oligodendroglial differentiation, and thus may be involved in the secretion of a cell proliferation factor (Younes-Rapozo et al. 2009; Harauz and Boggs 2013; Smith et al. 2013; Ozgen et al. 2014). Involvement in the regulation of secreted growth factors is implicated in a study in which neurite growth and process branching complexity was increased in $\mathrm{N} 2 \mathrm{a}$ neuronal cells that were co-cultured with N19-oligodendrocytes transfected with 21.5-kDa MBP, and as well in $\mathrm{N} 2$ a cells grown in media obtained from these N19-oligodendrocyte cultures (Smith et al. 2013). These effects were no longer observed when 21.5-kDa MBP had a double-nuclear export signal at its N-terminus, or when a double-nuclear localization signal was added to the $\mathrm{N}$ terminus of $18.5-\mathrm{kDa} \mathrm{MBP}$, indicating that they were specific to $21.5-\mathrm{kDa} \mathrm{MBP}$ and that exon-II is a critical component for MBP's involvement in the stimulation of cell growth (Smith et al. 2013; Ozgen et al. 2014).

The expression of $21.5-\mathrm{kDa} \mathrm{MBP}$ is highest in oligodendrocytes during active myelination, and has been shown to be up-regulated during attempts at remyelination in multiple sclerosis, suggesting that $21.5-\mathrm{kDa} \mathrm{MBP}$ has a role in the regulation of myelination (Barbarese et al. 1978; Capello et al. 1997; Pedraza et al. 1997; DeBruin et al. 2006; Uruse et al. 2014). The implications of the potential role of 21.5-kDa MBP in regulating myelination and remyelination are significant to the understanding of demyelinating diseases like MS. It is, therefore, crucial to investigate potential nuclear targets of $21.5-\mathrm{kDa} \mathrm{MBP}$ to characterize signaling pathways in which it may be involved.

To understand fully the nature of the protein-protein or protein-DNA interactions of 21.5-kDa MBP, a biophysical analysis must be conducted on the protein to investigate its secondary and tertiary structure. One technique used to analyze protein structure is Circular Dichroism (CD) spectroscopy, which measures a protein's differential absorbance of circularly polarized light. In the far-ultraviolet (UV) range (190-250 $\mathrm{nm}$ ) it can yield information about secondary structures in the protein based on comparison to previously developed well-defined spectra. In the near-UV range (250-350 $\mathrm{nm})$, we can get information on the tertiary structure of the protein (Whitmore and Wallace 2007).

In addition to $\mathrm{CD}$, fluorescence spectroscopy can be used in conjunction with a probe such as 8anilinonaphthalene-1-sulfonic acid (ANS) to study the changes in the tertiary structure of the protein in different conditions. The ANS probe has a high affinity for hydrophobic environments, and produces a strong emission spectrum between $\sim 450-500 \mathrm{~nm}$ only when sequestered in such an environment. When a protein is partially folded, the proportion of localized, solvent-exposed hydrophobic pockets to which ANS may bind is theoretically increased, and a stronger emission signal can be detected (Brand and Gohlke 1972).

Lastly, it is crucial to investigate the effects of the divalent cation $\mathrm{Zn}^{2+}$ on MBP structure due to this metal's high prevalence in CNS myelin. It has been previously suggested that $\mathrm{Zn}^{2+}$ may have an effect on MBP folding (Cuajungco and Lees 1997; Tsang et al. 1997; Majava et al. 2010; Smith et al. 2010).

It is essential to understand myelin architecture to decipher the onset and pathogenesis of MS. The objectives of our research group are to determine how this key basic protein of the myelin sheath interacts with membranes and other proteins to form and stabilize healthy myelin, and how modifications to this protein participate in the onset and pathogenesis of MS. The study presented here is part of this overall program.

\section{Materials and Methods}

\section{Reagents}

1-Anilinonaphthalene-8-Sulfonic Acid (ANS) was purchased from Invitrogen (Carlsbad, CA) and electrophoresis grade acrylamide was purchased from ICN Biomedicals (Costa Mesa, CA). Other chemicals were reagent grade and purchased from either Fisher Scientific (Unionville, ON) or Sigma-Aldrich (Oakville, ON).

\section{Buffers}

Lysis Buffer (8 M urea, $100 \mathrm{mM} \mathrm{NaH} \mathrm{PO}_{4}, 500 \mathrm{mM}$ $\mathrm{NaCl}, 5 \mathrm{mM}$ Tris- $\mathrm{HCl}, 10 \mathrm{mM}$ imidazole, $1 \%$ v/v Tween-20, pH 8.0); FPLC $\mathrm{Ni}^{2+}$-affinity Wash Buffer (8 M urea, 100 $\mathrm{mM} \mathrm{NaH} \mathrm{PO}_{4}, 500 \mathrm{mM} \mathrm{NaCl}, 5 \mathrm{mM}$ Tris- $\mathrm{HCl}, 10 \mathrm{mM}$ imidazole, $\mathrm{pH}$ 8.0); FPLC $\mathrm{Ni}^{2+}$-affinity Elution Buffer $(8 \mathrm{M}$ urea, $100 \mathrm{mM} \mathrm{NaH} \mathrm{PO}_{4}, 500 \mathrm{mM} \mathrm{NaCl}, 5 \mathrm{mM}$ Tris-HCl, 10 $\mathrm{mM}$ imidazole, $\mathrm{pH} 4.5)$; cation exchange IEX Buffer (6 M urea, $80 \mathrm{mM}$ glycine, $\mathrm{pH} 10.0$ ); cation exchange Charge Buffer (1 M NaCl); final dialysis Buffer A (50 mM Tris- $\mathrm{HCl}$,

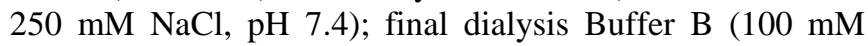
$\mathrm{NaCl})$.

\section{Recombinant protein over-expresison}

The Escherichia coli BL-21-Codon Plus (DE3)-RP cells (Stratagene) were transformed with pET22b(+) plasmid containing the gene for $21.5-\mathrm{kDa}$ rmMBP (recombinant murine MBP) with a $\mathrm{C}$-terminal hexa-histidine tag, under the control of the lac operon. Transformed E. coli was grown in $300 \mu \mathrm{L}$ SOC media at $37^{\circ} \mathrm{C}$ with shaking for one hour, and was then added to $10 \mathrm{~mL}$ LB media with $50 \mu \mathrm{g} / \mathrm{mL}$ ampicillin and $34 \mu \mathrm{g} / \mathrm{mL}$ chloramphenicol, for incubation overnight at $37^{\circ} \mathrm{C}$ with shaking. The overnight culture was added to $250 \mathrm{~mL} \mathrm{LB}$ media containing $50 \mu \mathrm{g} / \mathrm{mL}$ ampicillin and $34 \mu \mathrm{g} / \mathrm{mL}$ chloramphenicol, and incubated at $37^{\circ} \mathrm{C}$ with shaking until the absorbance at $600 \mathrm{~nm}\left(\mathrm{~A}_{600}\right)$ reached between 0.6-0.8 (arbitrary units), as measured by an 
Ultraspec-2000® (Pharmacia-Biotech, QC, Canada). The culture was centrifuged at $2000 \mathrm{rpm}$ (Beckman-Coulter Rotor JA-10) for 15 minutes at $20^{\circ} \mathrm{C}$. The cell pellet was resuspended in $1.5 \mathrm{~L}$ of M9 media, pre-warmed at $37^{\circ} \mathrm{C}$, containing $30 \mathrm{~mL}$ of $20 \%$ glucose solution, $3 \mathrm{~mL}$ of $1 \mathrm{M}$ $\mathrm{MgSO}_{4}, 150 \mu \mathrm{L}$ of $1 \mathrm{M} \mathrm{CaCl}_{2}, 1.5 \mathrm{~mL}$ of $50 \mu \mathrm{g} / \mathrm{mL}$ ampicillin, and $1.5 \mathrm{~mL}$ of $34 \mu \mathrm{g} / \mathrm{mL}$ chloramphenicol. The M9 culture was incubated at $37^{\circ} \mathrm{C}$ with shaking until the $\mathrm{A}_{600}$ reached 0.8 . A $1-\mathrm{mL}$ pre-induction sample was taken, and then $1.5 \mathrm{~mL}$ of $0.238 \mathrm{~g} / \mathrm{mL}$ isopropyl $\beta-\mathrm{D}-1-$ thiogalactopyranoside (IPTG), a molecular mimic of allolactose, was added to the M9 media to induce expression of His $_{6}$-tagged 21.5-MBP.

The M9 culture was then incubated at $37^{\circ} \mathrm{C}$ with shaking for approximately three-four hours. A $1-\mathrm{mL}$ postinduction sample was taken, and the culture was centrifuged at $6000 \mathrm{rpm}$ (Beckman-Coulter Rotor JA-10) for 25 minutes at $4{ }^{\circ} \mathrm{C}$. The pellet was stored at $-20^{\circ} \mathrm{C}$, and pre- and postIPTG induction samples were analyzed using a $12 \%$ bisacrylamide sodium dodecyl sulfate polyacrylamide gel electrophoresis (SDS-PAGE) (Supplementary Figure S1).

The cell pellet was thawed on ice and homogenized in Lysis Buffer ( $8 \mathrm{M}$ urea, $100 \mathrm{mM} \mathrm{NaH}_{2} \mathrm{PO}_{4}, 500 \mathrm{mM} \mathrm{NaCl}, 5$ $\mathrm{mM}$ Tris-HCl, $10 \mathrm{mM}$ imidazole, $1 \%$ v/v Tween-20, $\mathrm{pH}$ 8.0) at room temperature. Cell lysate was sonicated for 6 pulses of 10 seconds, with 10 -second increments between pulses, and stirred at room temperature for 20 minutes. The lysate was then centrifuged at 15,000 rpm (Beckman-Coulter Rotor JA-25.5) for 30 minutes at $4^{\circ} \mathrm{C}$. The resulting supernatant was filtered through a $0.45-\mu \mathrm{m}$ membrane.

\section{Recombinant protein purification by $\mathrm{Ni}^{2+}$-chelation chromatography}

Fast Protein Liquid Chromatography (FPLC) was first used to purify 21.5-kDa MBP from the aforementioned supernatant using a BioRad-DuoFlow ${ }^{\circledR}$ apparatus (BioRad Laboratories Ltd., Mississauga, ON). An amount of $8 \mathrm{~mL}$ of a $50 \%$ slurry of Qiagen Ni-NTA agarose resin (QIAGEN Sciences, Germantown, MD, USA) was used to produce a 4 $\mathrm{mL}$ column bed volume. The mobile phase was composed of Wash Buffer ( $8 \mathrm{M}$ urea, $100 \mathrm{mM} \mathrm{NaH} \mathrm{PO}_{4}, 500 \mathrm{mM} \mathrm{NaCl}, 5$ $\mathrm{mM}$ Tris- $\mathrm{HCl}, 10 \mathrm{mM}$ imidazole, $\mathrm{pH}$ 8.0) and Elution Buffer (8 M urea, $100 \mathrm{mM} \mathrm{NaH} \mathrm{PO}_{4}, 500 \mathrm{mM} \mathrm{NaCl}, 5 \mathrm{mM}$ Tris$\mathrm{HCl}, 10 \mathrm{mM}$ imidazole, $\mathrm{pH} 4.5$ ). Each buffer was filtered through a $0.45-\mu \mathrm{m}$ membrane prior to chromatography. The run was performed at $1 \mathrm{~mL} \mathrm{~min}^{-1}$ and protein absorbance was measured at $280 \mathrm{~nm}$. The MBP was eluted with $20 \mathrm{~mL}$ Elution Buffer, and 1-mL fractions were collected automatically. The composition of the fractions, flowthrough, and wash steps was then analyzed using SDS-PAGE (Supplementary Figure S2). All of the fractions containing a band at $\sim 22-\mathrm{kDa}$ on the SDS-PAGE gel were pooled in 6000-8000 MWCO dialysis tubing, and dialyzed overnight against $2 \mathrm{~L}$ of buffer containing $6 \mathrm{M}$ urea and $80 \mathrm{mM}$ glycine at a $\mathrm{pH}$ of 10.0, to remove the $\mathrm{NaCl}$ prior to the next step.

\section{Cation exchange chromatography}

The post-dialyzed sample was further purified by cation exchange chromatography using FPLC with a 1-mL Pall AcroSep $^{\circledR}$ cation exchange column (Pall Life Sciences, Ann Arbor, MI, USA). The mobile phase was composed of IEX Buffer (6 M urea, $80 \mathrm{mM}$ glycine, $\mathrm{pH}$ 10.0) and Charge Buffer (IEX Buffer with additional $1 \mathrm{M} \mathrm{NaCl}$ ), both of which had been filtered through a $0.45-\mu \mathrm{m}$ membrane prior to chromatography. Chromatography was run at $1 \mathrm{~mL} \mathrm{~min}{ }^{-1}$ and the protein absorbance was measured at $280 \mathrm{~nm}$. A linear salt gradient was established over $10 \mathrm{~mL}$ to a final salt concentration of $500 \mathrm{mM}$, and $1-\mathrm{mL}$ fractions were collected automatically. The composition of the fractions, flowthrough, and wash steps was then analyzed using SDS-PAGE (Supplementary Figure S2). All fractions containing a band at the $\sim 22-\mathrm{kDa}$ position on the SDS-polyacrylamide gel were pooled in 6000-8000 MWCO dialysis tubing, and dialyzed against $2 \times 2 \mathrm{~L}$ of Buffer A (50 mM Tris- $\mathrm{HCl}, 250 \mathrm{mM} \mathrm{NaCl}$, $\mathrm{pH} 7.4), 2 \times 2 \mathrm{~L}$ Buffer $\mathrm{B}(100 \mathrm{mM} \mathrm{NaCl})$, and $4 \times 2 \mathrm{~L}$ double-distilled water. Buffer changes were made approximately every four hours. The purity of the postdialysis sample was analyzed using high-performance liquid chromatography HPLC (Supplementary Figure S3), and the protein was flash-frozen in liquid nitrogen and lyophilized.

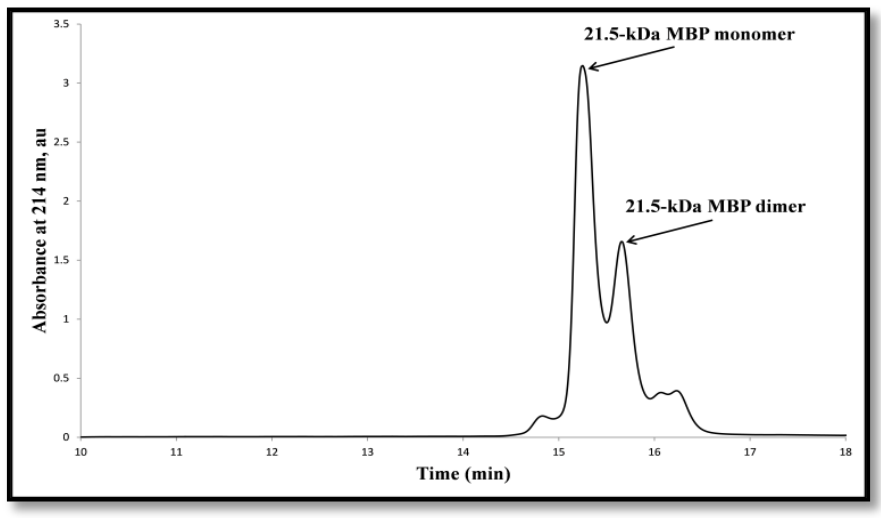

Figure 1. An HPLC chromatogram for analysis of purity of 21.5-kDa MBP purified by HPLC. The mobile phase consisted of acetonitrile, and the ionpairing agent was $0.1 \%$ TFA. Detection was performed at $214 \mathrm{~nm}$ and 280 $\mathrm{nm}$ (data not shown). The elution gradient began at $75 \%$ sterile water + $0.1 \%$ TFA and $25 \%$ acetonitrile and $0.1 \%$ TFA. Acetonitrile $+0.1 \%$ TFA was increased to $40 \%$ over 15 minutes at $1 \%$ per minute. It was then increased further to $100 \%$ over 2 minutes. The peak occurring at $\sim 15.00$ minutes corresponds to $21.5-\mathrm{kDa} \mathrm{MBP}$ monomers, and the peak at $\sim 15.50$ minutes corresponds to $21.5-\mathrm{kDa}$ MBP dimers. The dialyzed cationexchange fractions were further purified using HPLC chromatography.

\section{High-performance liquid chromatography}

The His $_{6}$-tagged 21.5-kDa MBP was purified in a final step using reversed-phase high-performance liquid chromatography (HPLC) on a Waters (Mississauga, ON) apparatus with a Symmetry 300, C18, $5 \mathrm{~mm}, 4.6$ x $250 \mathrm{~mm}$ column (Waters Corp., Milford, MA, USA) (Figure 1). The mobile phase consisted of acetonitrile, and the ion-pairing 


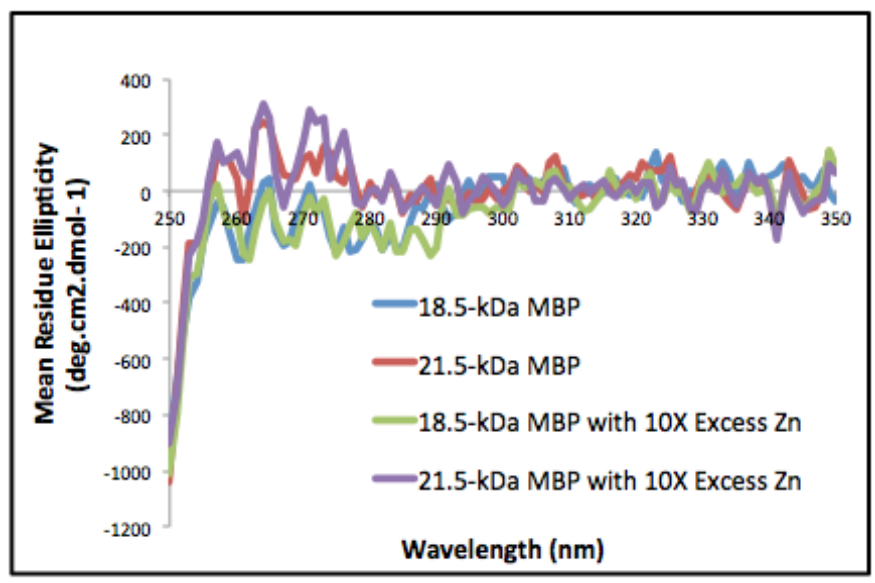

Figure 2. Near-UV CD spectroscopy of $25 \mu \mathrm{M} 18.5-\mathrm{kDa}$ and $21.5-\mathrm{kDa}$ MBP, in the presence and absence of $10 X$ excess $\mathrm{Zn}^{2+}$, with $20 \mathrm{mM}$ HEPES buffer. Here, $1 \mathrm{mM}$ TCEP was added to the $21.5-\mathrm{kDa}$ MBP samples to reduce dimers linked by cysteine residues.

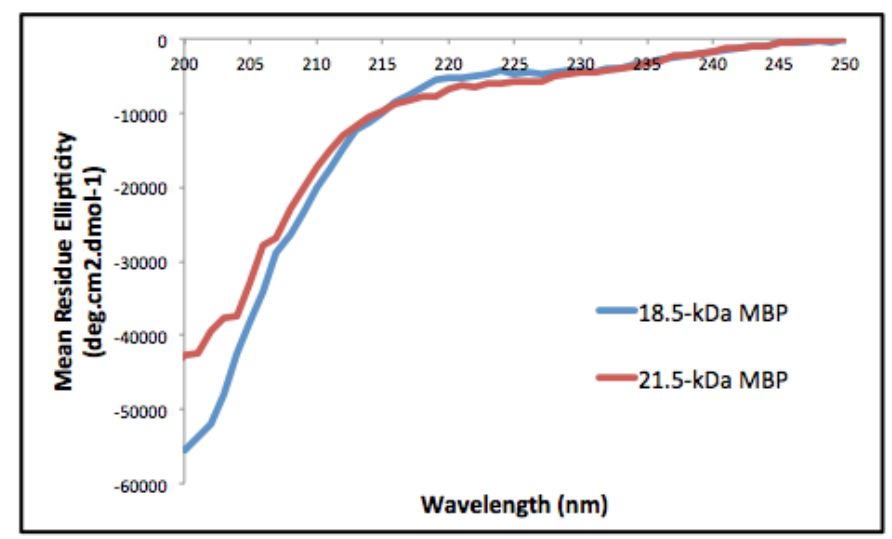

Figure 3. Far-UV CD spectroscopy of $5 \mu \mathrm{M} 18.5-\mathrm{kDa}$ and 21.5-kDa MBP in $10 \mathrm{mM}$ phosphate buffer. The $21.5-\mathrm{kDa}$ MBP sample also contained $1 \mathrm{mM}$ TCEP to reduce dimers linked by cysteine residues.

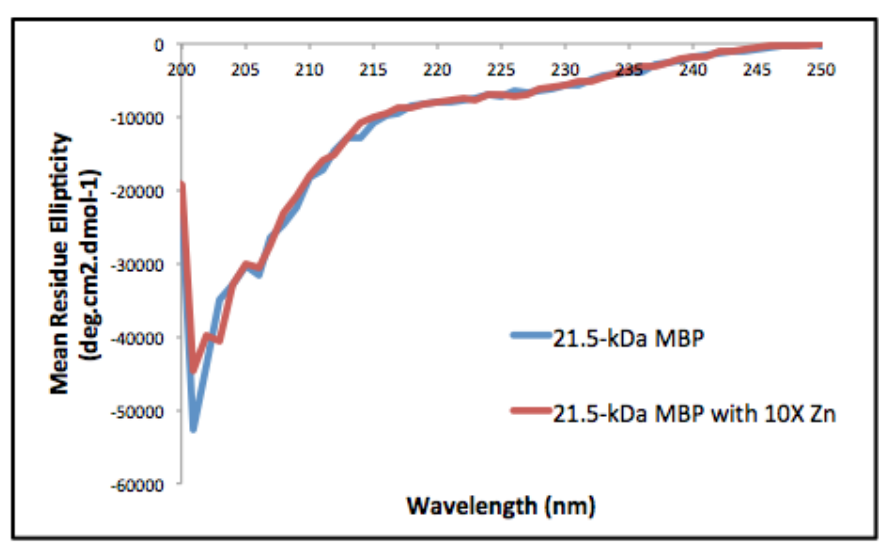

Figure 4. Far-UV CD spectroscopy of $5 \mu \mathrm{M} 21.5-\mathrm{kDa} M B P$, in the presence and absence of $10 \mathrm{X}$ excess $\mathrm{Zn}^{2+}$, in $10 \mathrm{mM}$ HEPES buffer with $1 \mathrm{mM}$ TCEP to reduce dimers linked by cysteine residues. agent was $0.1 \%$ trifluoroacetic acid (TFA). The column temperature was maintained at $40^{\circ} \mathrm{C}$, and the flow-rate at 1 $\mathrm{mL} \min ^{-1}$. Detection was performed at $214 \mathrm{~nm}$ and $280 \mathrm{~nm}$. Protein was eluted from the column beginning at an elution gradient of $75 \%$ Solvent A (sterile water and $0.1 \%$ TFA) and $25 \%$ Solvent B (acetonitrile and $0.1 \%$ TFA), followed by increasing Solvent B at $1 \%$ per minute to $40 \%$. Solvent B was then increased to $100 \%$. Fractions containing MBP were collected and flash-frozen in liquid nitrogen and lyophilized.

\section{Assessing protein purity}

In addition to protein purification, HPLC was used as an analytical tool to assess the purity of the resultant MBP stock (Bamm et al. 2011). The MBP was solubilized in water to a concentration of $2 \mathrm{mg} \mathrm{mL}^{-1}$ and a $50 \mu \mathrm{L}$ sample was applied to the apparatus following the protocol outlined for purification. Protein concentration was determined by $\mathrm{A}_{280}$ and the extinction coefficient $\left(\varepsilon=19,940 \mathrm{M}^{-1} \mathrm{~cm}^{-1}\right)$.

SDS-PAGE was also used to confirm the purity of the protein stock and gain insight into the potential identity of constituents other than full-length 21.5-kDa MBP. This technique also allowed for the identification of homodimers of MBP that would be expected to be located at approximately $44 \mathrm{kDa}$ on the SDS-polyacrylamide gel.

\section{MBP dimer reduction}

To eliminate disulfide-linked covalent homodimers of 21.5-kDa MBP, the reducing agent tris(2carboxyethyl)phosphine (TCEP) was added to $2 \mathrm{mg} \mathrm{mL}^{-1}$ 21.5-kDa MBP to give a final concentration of $1 \mathrm{mM}$. The reaction mixture was incubated at room temperature for one hour prior to analysis by HPLC at $214 \mathrm{~nm}$, as described above.

\section{Incubation of $\mathrm{Zn}^{2+}$ with 21.5-kDa MBP}

The MBP at concentrations of $0.5 \mathrm{mg} \mathrm{mL}^{-1}$ and $0.05 \mathrm{mg}$ $\mathrm{mL}^{-1}$ was incubated in $20 \mathrm{mM}$ 4-(2-hydroxyethyl)-1piperazineethanesulfonic acid (HEPES) buffer for one hour at room temperature and at $37^{\circ} \mathrm{C}$, in the presence and absence of $10 \mathrm{X}$ excess $\mathrm{Zn}^{2+}$. Each sample condition was incubated in duplicate, and one of each sample was mixed with either reducing $(0.05 \% \quad \beta$-mercaptoethanol $)$ or nonreducing sample buffer, boiled for $\sim 45$ seconds, and analyzed by SDS-PAGE.

\section{Circular dichroism spectroscopy}

Circular dichroism (CD) spectroscopy was performed using a Jasco J-815 spectropolarimeter (Japan Spectroscopic Co., Tokyo, Japan) with both 18.5-kDa and 21.5-kDa MBP. Near-UV (250-350 nm) and far-UV CD scans (190-250 nm) were carried out at protein concentrations of $25 \mu \mathrm{M}$ and 5 $\mu \mathrm{M}$, respectively, and a total sample volume of $200 \mu \mathrm{L}$ in a quartz cuvette of path length of $1 \mathrm{~mm}$ (Figures 2-4). Data were collected at room temperature, and each scan was repeated three times on a single protein preparation. The 21.5-kDa and 18.5-kDa MBP were each solubilized in 10 

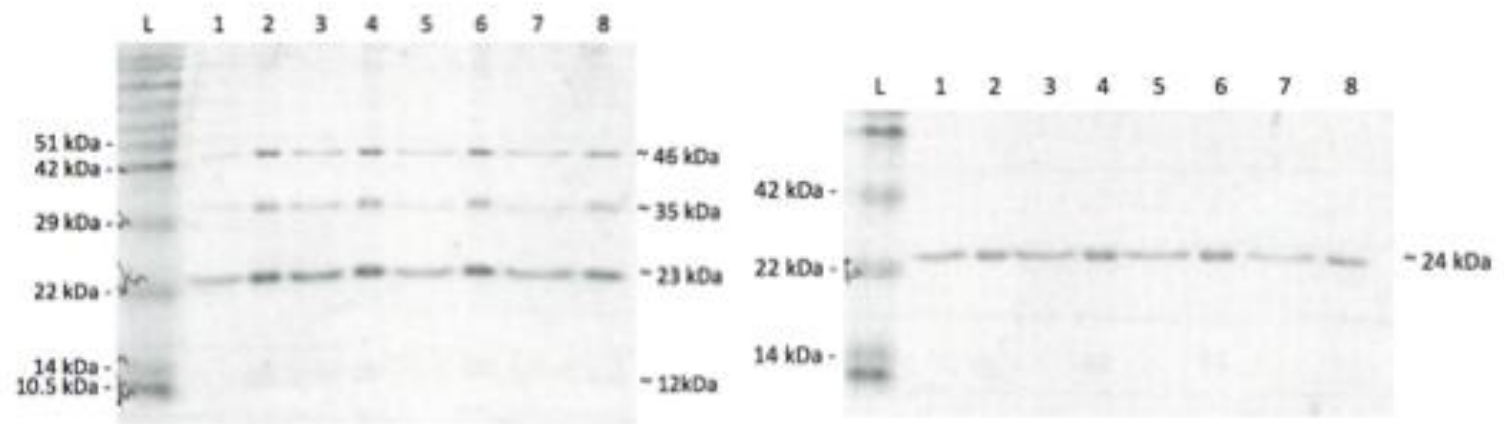

Figure 5. A $14 \%$ SDS-polyacrylamide gel of 21.5-kDa MBP incubated in the presence and absence of TCEP and 10X excess $\mathrm{Zn}{ }^{2+}$. A: $20-\mu \mathrm{L}$ samples contained $20 \mathrm{mM}$ HEPES and were prepared by the addition of non-reducing loading dye to $16 \mu \mathrm{L}$ of each sample. Odd lanes contain $0.05 \mathrm{mg} \mathrm{mL}^{-1}$ protein $\left(0.8 \mu \mathrm{g}\right.$ per well) and even lanes contain $0.5 \mathrm{mg} \mathrm{mL}^{-1}$ protein $\left(8.0 \mu \mathrm{g}\right.$ per wel). Lanes $5-8$ contain $10 \mathrm{X}$ excess $\mathrm{Zn}^{2}$. Samples were incubated for one hour prior to loading at either room temperature (lanes 1,2, 5, and 6), or at $37^{\circ} \mathrm{C}$ (lanes $3,4,7$, and 8). Samples were then boiled for two minutes prior to loading. Lane 1 contains the Pink Plus Protein Ladder from Biorad. B: Samples were prepared as the samples in gel A except a reducing dye was used for loading. The gels were stained with Coomassie Brilliant Blue for 10 minutes, and destained with $2 \%$ methanol and $1 \%$ acetic acid.

$\mathrm{mM}$ phosphate buffer, $\mathrm{pH} 7.4$, and 21.5-kDa MBP was also

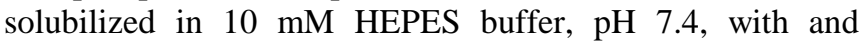
without $50 \mu \mathrm{M} \mathrm{ZnCl}$. All samples of $21.5-\mathrm{kDa} \mathrm{MBP}$ contained $1 \mathrm{mM}$ TCEP-HCl to reduce dimers. Buffer blanks were subtracted from each measurement, which was taken as an average of the 3 scans for each sample. Data were normalized to mean residue ellipticity.

\section{Fluorescence spectroscopy}

The $21.5-\mathrm{kDa}$ and $18.5-\mathrm{kDa}$ MBP were solubilized to a final concentration of $5 \mu \mathrm{M}$ in $20 \mathrm{mM}$ HEPES, pH 7.4, with and without $50 \mu \mathrm{M} \mathrm{ZnCl}$, in a total volume of $80 \mu \mathrm{L}$. Samples also contained $50 \mu \mathrm{M}$ of the dye 8anilinonaphthalene-1-sulfonic acid (ANS), which was used as a probe for the presence of solvent exposed hydrophobic pockets within MBP. A Photon Technology International (PTI) fluorimeter (Photon Technology International Inc., London, ON), and a $45-\mu \mathrm{L}$ quartz cuvette with 3-mm pathlength, were used to measure each sample in triplicate at room temperature. The slit widths were set to $2 \mathrm{~nm}$ for excitation and $6 \mathrm{~nm}$ for emission, and gain was set to $1.0 \mathrm{~V}$ at $350 \mathrm{~nm}$ for all measurements. Samples were excited at 350 $\mathrm{nm}$, and emission was measured at 400-600 nm. Scans of buffer samples were subtracted from protein-containing sample scans before presentation and analysis.

\section{Results and Discussion}

\section{Purification and yield of 21.5-kDa rmMBP}

This study utilized a purification protocol for hexahistidine-tagged $21.5-\mathrm{kDa}$ rmMBP that employed $\mathrm{Ni}^{2+}$ chelation chromatography, cation exchange chromatography, and high-performance liquid chromatography in tandem. One notable modification in our procedure is the use of a different $\mathrm{pH}$ rather than a different imidazole concentration for the binding and elution buffers from the $\mathrm{Ni}^{2+}$-affinity column the pI of histidine is 7.6 , so this residue would be fully protonated at $\mathrm{pH} 4.5$ and would elute from the column. The yield from $1.5 \mathrm{~L} \mathrm{M} 9$ media was roughly $12 \mathrm{mg}$ of protein, and the purity (as determined by the integrated peak areas on the HPLC profile) was consistently above 90\%. This purification procedure produced protein that was pure enough to be used for $\mathrm{CD}$ and fluorescence spectroscopy analysis.

\section{Analysis of purity of 21.5-kDa MBP}

In preparation for the biophysical characterization of 21.5-kDa MBP using circular dichroism and fluorescence spectroscopy, the MBP stock was analyzed using HPLC to confirm purity and ensure that the protein was in monomeric form. The HPLC chromatogram of the absorbance of 21.5$\mathrm{kDa}$ MBP at $214 \mathrm{~nm}$ showed a slightly smaller peak tightly associated with the main peak in a $50 \mu \mathrm{L}$ analytical sample (Figure 1). This product was hypothesized to represent MBP homodimers due to disulfide bonding of the single cysteine residue encoded within exon-II. A $2 \mathrm{mg} \mathrm{mL}^{-1}$ sample of the MBP stock was then analyzed using SDS-PAGE (32 $\mu \mathrm{g}$ protein per well) and non-reducing loading dye to observe whether a band representative of MBP dimers would appear at approximately $44 \mathrm{kDa}$. Four bands appeared on this gel: one at $\sim 23 \mathrm{kDa}$, representing full-length 21.5-kDa MBP; one at $\sim 12 \mathrm{kDa}$ (faint and visible only on original gel), which was likely a degraded form of $21.5-\mathrm{kDa} \mathrm{MBP}$; one at $\sim 46 \mathrm{kDa}$, representing homodimers of 21.5-kDa MBP; and one at $\sim 35$ $\mathrm{kDa}$, which was likely a heterodimer of full-length and degraded MBP (Figure 5A). Identical samples loaded onto an SDS-polyacrylamide gel with reducing buffer produced only a single band at approximately $24 \mathrm{kDa}$ (Figure 5B). The number and location of bands were consistent across samples and within treatments (reducing or non-reducing 
sample buffer). From these results it was concluded that the smaller peak that was tightly associated with the larger, main peak on the HPLC chromatogram represented MBP homodimers.

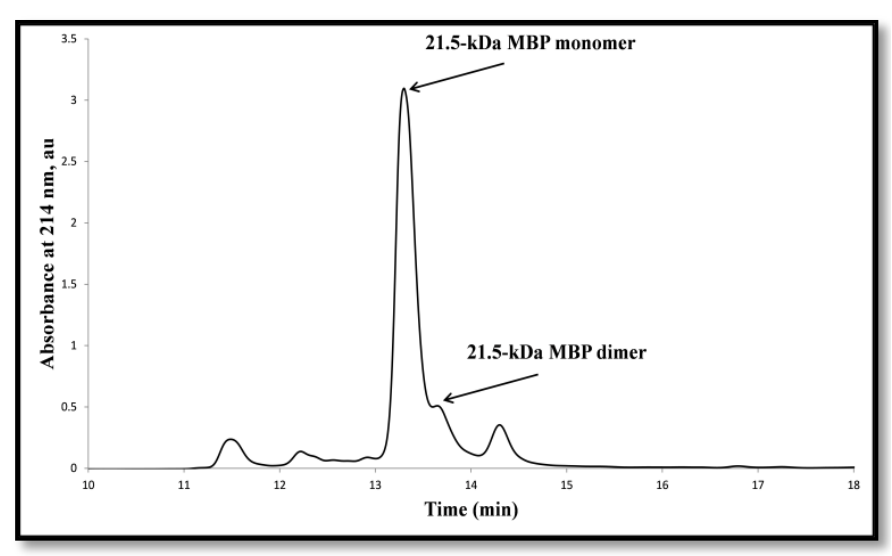

Figure 6. An HPLC chromatogram for analysis of the effects of $1 \mathrm{mM}$ TCEP on peak profile. The $1 \mathrm{mM} \mathrm{TCEP-HCl}$ was added to $2 \mathrm{mg} \mathrm{mL}^{-1}$ of 21.5-kDa MBP and incubated at room temperature for one hour before HPLC. The mobile phase consisted of acetonitrile, and the ion-pairing agent was $0.1 \%$ TFA. Detection was performed at $214 \mathrm{~nm}$ and $280 \mathrm{~nm}$ (data not shown). The elution gradient began at $75 \%$ sterile water $+0.1 \%$ TFA and $25 \%$ acetonitrile and $0.1 \%$ TFA. Acetonitrile + $0.1 \%$ TFA was increased to $40 \%$ over 15 minutes at $1 \%$ per minute. It was then increased further to $100 \%$ over 2 minutes. The peak occurring at $\sim 13.50$ minutes corresponds to $21.5-\mathrm{kDa}$ MBP monomers, and the peak at $\sim 15.75$ minutes corresponds to $21.5-\mathrm{kDa}$ MBP dimers.

The presence of MBP homodimers would greatly skew the data obtained from CD and fluorescence spectroscopy, which were used in this study to characterize the monomeric structure of the protein. To eliminate dimers, $1 \mathrm{mM}$ of the reducing agent TCEP was added to a sample of $2 \mathrm{mg} \mathrm{mL}^{-1}$ of $21.5-\mathrm{kDa}$ MBP, and incubated for one hour at room temperature. The purpose of this step was to observe whether the disulfide bond would be successfully reduced, producing a sample containing only the monomeric form of the protein. This reaction was then analyzed using HPLC. A large reduction in this second peak, to less than $10 \%$ of the total protein, was observed in a $50-\mu \mathrm{L}$ sample (Figure 6).

\section{Circular dichroism spectroscopy of MBP in the presence and absence of 10X Excess $\mathrm{Zn}^{2+}$}

In this study, the CD spectra of $18.5-\mathrm{kDa}$ and $21.5-\mathrm{kDa}$ MBP in aqueous solution were compared to investigate any structural differences caused by the inclusion of the residues encoded by exon-II in the sequence of $21.5-\mathrm{kDa} \mathrm{MBP}$, as well as any differences caused by $\mathrm{Zn}^{2+}$-binding.

Near-UV CD spectroscopy of $5 \mu \mathrm{M} 18.5-\mathrm{kDa}$ and 21.5$\mathrm{kDa} \mathrm{MBP}$ in aqueous solution, in the presence and absence of $10 \mathrm{X}$ excess $\mathrm{Zn}^{2+}$, produced very similar mean residue ellipticity profiles between $250 \mathrm{~nm}$ and $350 \mathrm{~nm}$ (Figure 6). Between $290 \mathrm{~nm}$ to $350 \mathrm{~nm}$, the mean residue ellipticities for all samples oscillated around zero. The 21.5-kDa MBP sample yielded an overall maximum between $250 \mathrm{~nm}$ and $290 \mathrm{~nm}$, whereas 18.5-kDa MBP experienced an overall minimum in this range. The low signal-to-noise ratio of the curve in this region made it difficult to discern whether there were any true structural differences between the two isoforms of MBP.

Far-UV CD spectroscopy of $5 \mu \mathrm{M} 18.5-\mathrm{kDa}$ and 21.5$\mathrm{kDa}$ in $10 \mathrm{mM}$ phosphate buffer produced similar mean residue ellipticity profiles between $200 \mathrm{~nm}$ and $250 \mathrm{~nm}$ (Figure 6). The spectrum for $18.5-\mathrm{kDa} \mathrm{MBP}$ did show a slight increase between $218 \mathrm{~nm}$ and $222 \mathrm{~nm}$, and a decrease between $200 \mathrm{~nm}$ and $212 \mathrm{~nm}$, in comparison to $21.5-\mathrm{kDa}$ MBP. Far-UV CD spectroscopy of 21.5-kDa MBP with and without $10 \mathrm{X}$ excess zinc in $10 \mathrm{mM}$ HEPES buffer produced similar spectra between $200 \mathrm{~nm}$ and $250 \mathrm{~nm}$.

In the near-UV range $(250-350 \mathrm{~nm})$, there did not appear to be any detectable differences between $18.5-\mathrm{kDa}$ and $21.5-\mathrm{kDa}$ MBP preparations (Figure 6). In the far-UV range $(200-250 \mathrm{~nm})$, there appeared to be slight differences at $200 \mathrm{~nm}$ and $220 \mathrm{~nm}$. Since exon-II encodes a high proportion of positively-charged residues that would have a repulsive effect on other basic areas of the protein, it is unlikely that 21.5-kDa MBP would have significantly more ordered structure in aqueous solution than $18.5-\mathrm{kDa} \mathrm{MBP}$, which has been shown to be extended and flexible in the absence of a binding partner (Libich and Harauz 2008a, 2008b; Harauz et al. 2009; Libich et al. 2010; Nalugapalli et al. 2012). However, the $C D$ data suggest that some slight structural differences between the two isoforms may be present.

Zinc is present at high concentrations in myelin and has been found to have a role in the compaction of $18.5-\mathrm{kDa}$ MBP in vitro (Baran et al. 2010). Incubation of 50X excess $\mathrm{Zn}^{2+}$ with 0.05 and $0.5 \mathrm{mg} \mathrm{mL}^{-1} 21.5-\mathrm{kDa}$ MBP in $20 \mathrm{mM}$ HEPES buffer did not produce any detectable differences in mobility on an SDS-polyacrylamide gel from samples incubated without zinc. The effects of $\mathrm{Zn}^{2+}$-binding on the structure of $21.5-\mathrm{kDa}$ MBP were also analyzed using $\mathrm{CD}$ spectroscopy (Figures 2-4). The far-and near-UV spectra for 21.5-kDa MBP in the presence and absence of $\mathrm{Zn}^{2+}$ were very similar, and there was no noticeable effect of $\mathrm{Zn}^{2+}$ on the secondary structure of $21.5-\mathrm{kDa}$ MBP.

\section{Fluorescence spectroscopy of MBP in the presence and absence of $10 \mathrm{X}$ excess $\mathrm{Zn}^{2+}$}

Previously in our laboratory, ANS fluorescence had been used to probe the compaction of $18.5-\mathrm{kDa}$ MBP by zinc (Fayaz 2011). Then it was found that the spectral shift of ANS fluorescence occurs only when this fluorophore is sequestered in a hydrophobic pocket proffered by the protein, not in solution alone.. Here, the ANS-binding measured by fluorescence spectroscopy was further used to analyze the effects of $\mathrm{Zn}^{2+}$ on 18.5- and 21.5-kDa MBP conformation in solution (Figure 7). The fluorescence of ANS showed a steep increase in a $5 \mu \mathrm{M}$ sample of $21.5-\mathrm{kDa}$ MBP with $10 \mathrm{X}$ excess $\mathrm{Zn}^{2+}$, compared to samples without $\mathrm{Zn}^{2+}$, of about 


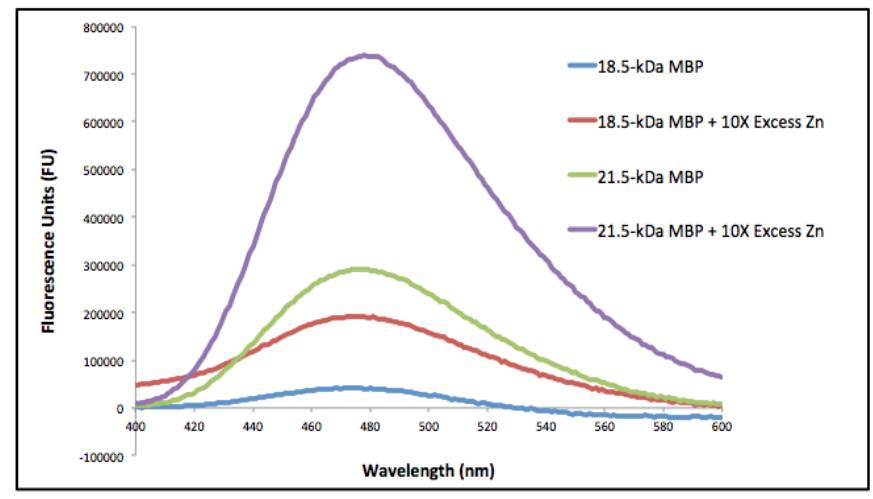

Figure 7. Fluorescence spectroscopy of $5 \mu \mathrm{M} 18.5-\mathrm{kDa}$ and 21.5-kDa MBP in $20 \mathrm{mM}$ HEPES buffer with 10X ANS fluorescent dye. The 21.5-kDa MBP samples also contained $1 \mathrm{mM}$ TCEP to reduce dimers linked by cysteine residues. Buffer scans containing all non-protein components were subtracted from protein scans.

450,000 fluorescence units (FU). Comparatively, ANS fluorescence increased approximately 150,000 FU between a $5 \mu \mathrm{M}$ sample of $18.5-\mathrm{kDa} \mathrm{MBP}$ to a $5-\mu \mathrm{M}$ sample of $18.5-$ $\mathrm{kDa}$ MBP containing 10X excess $\mathrm{Zn}^{2+}$. The maxima of all four fluorescence curves occurred at approximately $480 \mathrm{~nm}$.

In this experiment, samples of $18.5-\mathrm{kDa}$ and $21.5-\mathrm{kDa}$ MBP containing 10X excess $\mathrm{Zn}^{2+}$ showed an enhancement in ANS fluorescence, centered at approximately $480 \mathrm{~nm}$, compared to samples lacking $\mathrm{Zn}^{2+}$. The $\mathrm{Zn}^{2+}$ appeared to induce approximately $66 \%$ more of a conformational change in $21.5-\mathrm{kDa}$ MBP than in $18.5-\mathrm{kDa} \mathrm{MBP}$, as measured by fluorescence units.

\section{Conclusions}

The enhancement of ANS fluorescence upon protein binding can be sensitive to both local and global conformational changes. In circular dichroism spectroscopy, however, far-UV CD is specifically sensitive to secondary structural changes, whereas near-UV CD is sensitive to tertiary structural changes. Hence, given that $\mathrm{CD}$ data for 18.5- and 21.5-kDa MBP were very similar both with and without $\mathrm{Zn}^{2+}$, it is likely that the observed changes in ANS fluorescence are due to local conformational changes rather than global changes.

\section{Future Directions}

The product derived from a recombinant murine gene for $21.5-\mathrm{kDa}$ MBP that is linked to a hexa-histidine tag is thus far the most commonly used form of the protein for over-expression and purification, and was the system used for this study. Although the relatively small size of the His $_{6}$ tag renders data collected from experiments on the tagged protein fairly reliable, it is desirable to produce an expression system for a completely native form of the protein. This would eliminate the concern that the tag may be affecting data in any way. It would thus be beneficial to perform polymerase chain reaction (PCR) mutagenesis to remove the
His $_{6}$-tag from the rmMBP $21.5-\mathrm{kDa}$ gene, as has already been achieved for several $18.5-\mathrm{kDa}$ MBP variants (Smith et al. 2010). The CD and ANS fluorescence spectroscopy experiments could then be repeated on the native protein and compared to those performed in this study to observe any effects of the hexa-histidine tag.

Following these spectroscopic analyses, Isothermal Titration Calorimetry (ITC) would be worthwhile to perform to investigate the nature of any interactions between 21.5$\mathrm{kDa} \mathrm{MBP}$ and zinc, as has already been performed by us for the 18.5-kDa MBP isoform (Smith et al. 2010), and for plant dehydrins (Rahman et al. 2011). Parameters that can be determined in this way include stoichiometry and association constants.

Last but not least, this basic (positively-charged) protein may very well function as a transcription co-factor via its interactions with nuclear DNA sequences, yet to be elucidated (Harauz and Boggs 2013). In this light, chromatin immunoprecipitation (ChIP) would be a logical next step towards the characterization of the potential nuclear binding partners of 21.5-kDa MBP (Buck and Lieb 2004).

In MS, hyperdeimination and hypophosphorylation of $18.5-\mathrm{kDa}$ recapitulate an early developmental pattern, and contribute to physical demyelination and induction of autoimmunity. Disruption of its involvement in essential interaction networks in early childhood when myelin is still developing has been hypothesized to cause inherent initial myelin instability, and to confound remyelination attempts during MS (Bessonov et al. 2010, 2013; Bamm and Harauz 2014). The 21.5-kDa MBP isoform is operative in myelin formation (as reviewed above). Understanding its functions in the oligodendrocyte nucleus during proliferation, for example, may clear the way to greater insights into the mechanisms that lead to demyelination and remyelination in MS, and may lead to potential new targets for therapy.

\section{Acknowledgements}

Thank you to Dr. George Harauz, Dr. Kenrick Vassall, Dr. Vladimir Bamm, and the rest of the Harauz group for all of their help and encouragement. The work in Dr. Harauz's laboratory is supported by the Natural Sciences and Engineering Research Council (NSERC) of Canada, the Canada Research Chairs Program, and the Ontario-Manitoba endMS Regional Research and Training Network. This work was performed under the auspices of an NSERC USRA (Undergraduate Student Research Assistantship).

\section{References}

Bamm VV, De Avila M, Smith GST, Ahmed MAM and Harauz G. 2011. Structured functional domains of myelin basic protein: Cross-talk between actin polymerization and $\mathrm{Ca}^{2+}$-dependent calmodulin interaction. Biophysical Journal. 101(5):1248-1256. 
Bamm VV and Harauz G. 2008. Expression and purification of the active variant of recombinant murine Golliinteracting protein (GIP) - characterization of its phosphatase activity and interaction with Golli-BG21. Protein Expression and Purification. 62(1):36-43.

Bamm VV and Harauz G. 2014. Hemoglobin as a source of iron overload in multiple sclerosis - Does multiple sclerosis share risk factors with vascular disorders? Cellular and Molecular Life Sciences (Visions and Reflections). 71(10):1789-1798.

Baran C, Smith GST, Bamm VV, Harauz G, and Lee JS. 2010. Divalent cations induce a compaction of intrinsically-disordered myelin basic protein. Biochemical and Biophysical Research Communications. 391(1):224-229.

Barbarese E, Carson JH and Braun PE. 1978. Accumulation of the four myelin basic proteins in mouse brain during development. Journal of Neurochemistry. 31(4):779782.

Bessonov K, Bamm VV and Harauz G. 2010. Misincorporation of the proline homologue Aze (azetidine-2-carboxylic acid) into recombinant myelin basic protein. Phytochemistry. 71(5):502-507.

Bessonov K, Vassall KA and Harauz G. 2013. Parameterization of the proline analogue Aze (azetidine2-carboxylic acid) for molecular dynamics simulations and evaluation of its effect on homo-pentapeptide conformations. Journal of Molecular Graphics and Modelling. 39(1): 118-125.

Boggs JM, Rangaraj G, Heng YM, Liu Y and Harauz G. 2011. Myelin basic protein binds microtubules to a membrane surface and to actin filaments in vitro: effect of phosphorylation and deimination. Biochimica et Biophysica Acta - BioMembranes. 1808(3):761-773.

Boggs JM, Rangaraj G, Hill CMD, Bates IR, Heng YM and Harauz G. 2005. Effect of arginine loss in myelin basic protein, as occurs in its deiminated charge isoform, on mediation of actin polymerization and actin binding to a lipid membrane in vitro. Biochemistry. 44(9):35243534.

Brand L and Gohlke. 1972. Fluorescence probes for structure. Annual Reviews of Biochemistry. 41(1):843868.

Buck MJ and Lieb JD. 2004. ChIP-chip: considerations for the design, analysis, and application of genome-wide chromatin immunoprecipitation experiments. Genomics. 83(3):349-360.
Campagnoni AT and Campagnoni CW. 2008. The properties and Functions of the GOLLI Myelin Basic Proteins. In: Boggs JM, editor, Myelin Basic Protein: Nova Science Publishers, New York. pp 1-17

Capello E, Voskuhl RR, McFarland HF and Raine CS. 1997. Multiple sclerosis: re-expression of a developmental gene in chronic lesions correlates with remyelination. Annals of Neurology. 41(6):797-805.

Cuajungco MP and Lees GJ. 1997. Zinc metabolism in the brain: Relevance to human neurodegenerative disorders. Neurobiology of Disease. 4(3-4):137-169.

DeBruin LS, Haines JD, Bienzle D and Harauz G. 2006. Partitioning of myelin basic protein into membrane microdomains in a spontaneously demyelinating mouse model for multiple sclerosis. Biochemistry and Cell Biology (Special Edition on Membrane Proteins in Health and Disease). 84(6):993-1005.

Fayaz E. 2011. The 18.5-kDa myelin basic protein has loose tertiary contacts regulated by zinc and post-translational modification. M.Sc. Thesis, Department of Molecular and Cellular Biology, and Biophysics Interdepartmental Group, University of Guelph, Guelph, Canada.

Fyffe-Maricich SL, Karlo JC, Landreth GE and Miller RH. 2011. The ERK2 mitogen-activated protein kinase regulates the timing of oligodendrocyte differentiation. Journal of Neuroscience. 31(3):843-850.

Hanafy KA and Sloane JA. 2011. Regulation of remyelination in multiple sclerosis. FEBS Letters. 585(23):3821-3828

Harauz G and Boggs JM. 2013. Myelin management by the 18.5-kDa and 21.5-kDa classic isoforms of myelin basic protein. Journal of Neurochemistry. 125(3):334-361.

Harauz G, Ladizhansky V, Boggs JM. 2009. Structural polymorphism and multifunctionality of myelin basic protein. Biochemistry. 48(34):8094-8104.

Hill CMD and Harauz G. 2005. Charge effects modulate actin assembly by classic myelin basic protein isoforms. Biochemical and Biophysical Research Communications. 329(1):362-369.

Kelly SM and Price NC. 2000. The use of circular dichroism in the investigation of protein structure and function. Current Protein and Peptide Science. 1(4):349-384.

Libich DS, Ahmed MAM, Zhong L, Bamm VV, Ladizhansky V and Harauz G. 2010. Fuzzy complexes of myelin basic protein - NMR spectroscopic investigations of a polymorphic organizational linker of the central nervous system. Biochemistry and Cell Biology (Special Edition on CSBMCB Meeting on Protein Folding: Principles and Diseases). 88(2):143155. 
Libich DS and Harauz G. 2008a. Solution NMR and CD spectroscopy of an intrinsically-disordered, peripheral membrane protein: evaluation of aqueous and membrane-mimetic solvent conditions for studying the conformational adaptability of the $18.5-\mathrm{kDa}$ isoform of myelin basic protein (MBP). European Biophysics Journal. 37(6):1015-1029.

Libich DS and Harauz G. 2008b. Backbone dynamics of the $18.5 \mathrm{kDa}$ isoform of myelin basic protein reveals transient $\alpha$-helices and a calmodulin-binding site. Biophysical Journal. 94(12):4847-4866.

Majava V, Wang C, Myllykoski M, Kangas SM, Kang SU, Hayashi N, Baumgartel P, Heape AM, Lubec G and Kursula P. 2010. Structural analysis of the complex between calmodulin and full-length myelin basic protein, an intrinsically-disordered molecule. Amino Acids. 39(1):59-71.

Moscarello MA. 1997. Myelin basic protein, the "executive" molecule of the myelin membrane. In: Juurlink BHJ, Devon RM, Doucette JR, Nazarali AJ, Schreyer DJ, Verge VMK, editors. Cell Biology and Pathology of Myelin: Evolving Biological Concepts and Therapeutic Approaches: Plenum, New York. pp. 13-25.

Nagulapalli M, Parigi G, Yuan J, Gsponer J, Deraos G, Bamm VV, Harauz G, Matsoukas J, de Planque MRR, Gerothanassis IP, Babu MM, Luchinat C and Tzakos AG. 2012. Recognition pliability is coupled to structural heterogeneity: a calmodulin - intrinsically disordered binding region complex. Structure. 20(3):522-533.

Ozgen H, Kahya N, de Jong JC, Smith GST, Harauz G, Hoekstra D, Baron W. 2014. Regulation of cell proliferation by nucleocytoplasmic dynamics of postnatal and embryonic exon-II-containing MBP isoforms. Biochimica et Biophysica Acta (BBA) Molecular Cell Research. 1843(3):517-530.

Pedraza L, Fidler L, Staugaitis SM and Colman DR. 1997. The active transport of myelin basic protein into the nucleus suggests a regulatory role in myelination. Neuron. 18(4):579-589.

Rahman LN, Bamm VV, Voyer JAM, Smith GST, Chen L, Yaish MWF, Moffatt BA, Dutcher JR, Harauz G. 2011. Interactions of membrane-associated Thellungiella salsuginea dehydrins TsDHN-1 and TsDHN-2 with zinc - Stabilization of ordered secondary structure. Amino Acids. 40(5):1485-1502.

Readhead C, Takasashi N, Shine HD, Saavedra R, Sidman R and Hood L. 1990. Role of myelin basic protein in the formation of central nervous system myelin, Annals of the New York Academy of Sciences. 605(1):280-285.
Smith GST, Chen L, Bamm VV, Dutcher JR and Harauz G. 2010. The interaction of zinc with membrane-associated $18.5 \mathrm{kDa}$ myelin basic protein: an attenuated total reflectance-Fourier transform infrared spectroscopic study. Amino Acids. 39(3):739-750.

Smith GST, Homchaudhuri L, Boggs JM and Harauz G. 2012a. Classic 18.5- and 21.5-kDa myelin basic protein isoforms associate with cytoskeletal and SH3-domain proteins in the immortalized N19-oligodendroglial cell line stimulated by phorbol ester and IGF-1. Neurochemical Research. 37(6):1277-1295.

Smith GST, Paez PM, Spreuer V, Campagnoni CW, Boggs JM, Campagnoni AT and Harauz G. 2011. Classical 18.5- and 21.5- $\mathrm{kDa}$ isoforms of myelin basic protein inhibit calcium influx into oligodendroglial cells, in contrast to golli isoforms. Journal of Neuroscience Research. 89(4):467-480.

Smith GST, Samborska B, Hawley SP, Klaiman JM, Gillis TE, Jones N, Boggs JM and Harauz G. 2013. Nucleuslocalized 21.5-kDa myelin basic protein promotes oligodendrocyte proliferation and enhances neurite outgrowth in coculture, unlike the plasma membraneassociated 18.5-kDa isoform. Journal of Neuroscience Research. 91(3):349-362.

Smith GST, Seymour LV, Boggs JM and Harauz G. 2012b. The 21.5-kDa isoform of myelin basic protein has a nontraditional PY-nuclear-localization signal. Biochemical and Biophysical Research Communications. 422(4):670675.

Tsang D, Tsang YS, Ho WKK and Wong RNS. 1997. Myelin basic protein is a zinc-binding protein in brain: possible role in myelin compaction. Neurochemical Research. 22(7):811-819.

Tyszka JM, Readhead C, Bearer EL, Pautler RG and Jacobs RE. 2006. Statistical diffusion tensor histology reveals regional dysmyelination effects in the shiverer mouse mutant. NeuroImage. 29(4):1058-1065.

Uruse M, Yamamoto M, Sugawa M, Matsuura K, Sato Y, Seiwa C, Watanabe K, Aiso S and Asou H. 2014. Phase separation of myelin sheath in Triton X-114 solution: predominant localization of the $21.5-\mathrm{kDa}$ isoform of myelin basic protein in the lipid raft-associated domain. Journal of Biochemistry. 155(4):265-271.

Vassall KA, Bessonov K, De Avila M, Polverini E and Harauz G. 2013. The effects of threonine phosphorylation on the stability and dynamics of the central molecular switch region of 18.5-kDa myelin basic protein. PLoS One. 8(7):e68175-1-19. doi:10.1371/journal.pone.0068175. 
Whitmore L and Wallace BA. 2007. Protein secondary structure analyses from circular dichoism spectroscopy: Methods and reference databases. Biopolymers. 89(5):392-400.

Yamazaki Y, Hozumi Y, Kaneko K, Sugihara T, Fujii S, Goto K and Kato H. 2007. Modulatory effects of oligodendrocytes on the conduction velocity of action potentials along axons in the alveus of the rat hippocampal CA1 region. Neuron Glia Biology. 3(4):325-334.

Younes-Rapozo V, Felgueiras LO, Viana NL, Fierro IM, Barja-Fidalgo C, Manhaes AC and Barradas PC. 2009. A role for the MAPK/ ERKpathway in oligodendroglial differentiation in vitro: stage specific effects on cell branching. International Journal of Developmental Neuroscience. 27(8):757-768. 


\section{Supplementary Information}

\section{Abbreviations}

$\begin{array}{ll}\text { ANS } & \text { 8-Anilinonaphthalene-1-Sulfonic Acid } \\ \text { CD } & \text { Circular Dichroism } \\ \text { CNS } & \text { Central Nervous System } \\ \text { FPLC } & \text { Fast Protein Liquid Chromatography } \\ \text { HEPES } & \text { 4-(2-Hydroxyethyl)-1-Piperazineethanesulfonic Acid } \\ \text { HPLC } & \text { High-Performance Liquid Chromatography } \\ \text { IDP } & \text { Intrinsically-Disordered Protein } \\ \text { IPTG } & \text { Isopropyl } \beta \text {-D-1-thiogalactopyranoside } \\ \text { MBP } & \text { Myelin Basic Protein } \\ \text { MS } & \text { Multiple Sclerosis } \\ \text { PCR } & \text { Polymerase Chain Reaction } \\ \text { rmMBP } & \text { recombinant murine MBP } \\ \text { SDS-PAGE } & \text { Sodium Dodecyl Sulfate Polyacrylamide Gel Electrophoresis } \\ \text { SOC } & \text { Super Optimal Broth with Catabolite repression } \\ \text { TCEP } & \text { Tris(2-Carboxyethyl)Phosphine } \\ \text { TFA } & \text { Trifluoroacetic Acid } \\ \text { Tris } & \text { tris(hydroxymethyl)aminomethane }\end{array}$

Supplementary Figures

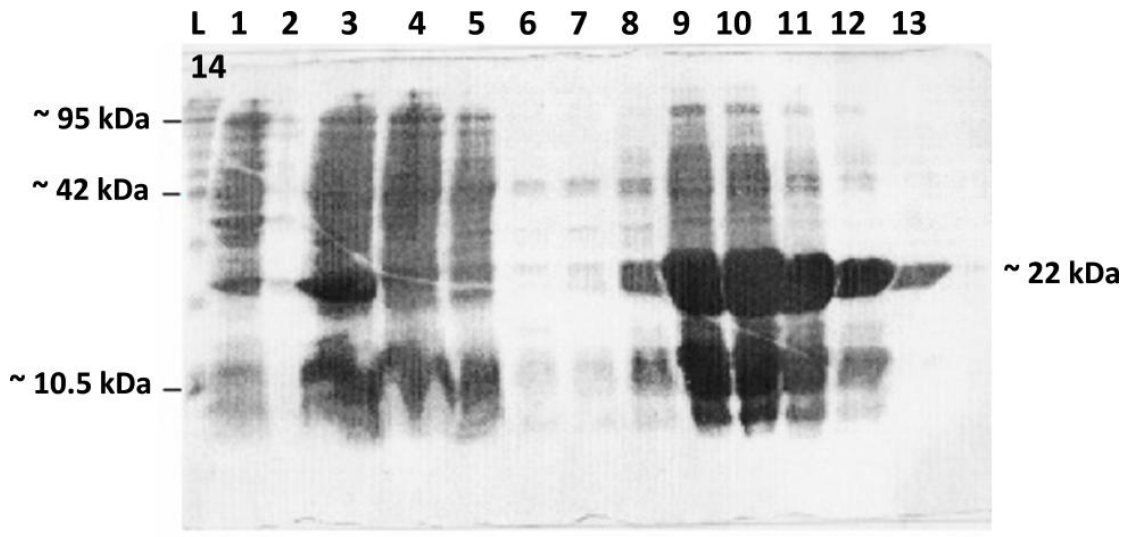

Figure S1. A 14\% SDS-polyacrylamide gel of 21.5-kDa MBP purified using Ni2-affinity column chromatography. The 20- $\mu \mathrm{L}$ samples were prepared by the

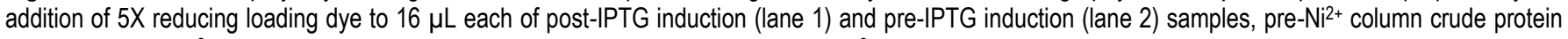
sample (lane 3), $\mathrm{Ni}^{2+}$ column flow-through and wash samples (lanes 4 and 5), and $\mathrm{Ni}^{2+}$ column fractions (lanes 6-14). Samples were boiled for two minutes prior to loading. Lane 1 contained a Pink Plus Protein Ladder from BioRad. The gel was stained with Coomassie Brilliant Blue for 10 minutes, and destained with $2 \%$ methanol and $1 \%$ acetic acid. The fractions that clearly contained over-expressed $21.5-\mathrm{kDa} \mathrm{MBP}$, within the range represented by lanes 7 through 13 , were collected for dialysis and further purification. 


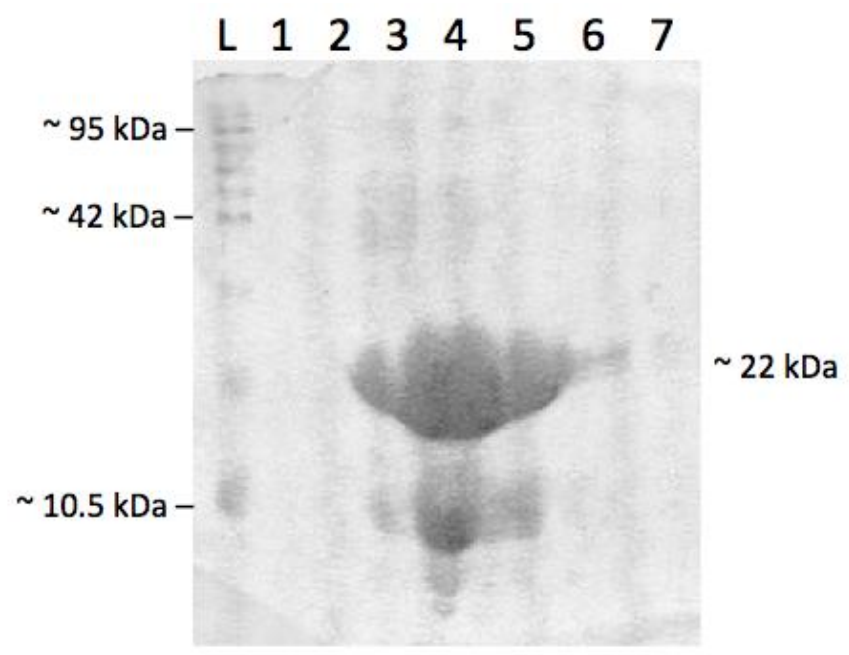

Figure S2. A $14 \%$ SDS-polyacrylamide gel of 21.5-kDa MBP purified using cation-exchange chromatography. The $20 \mu \mathrm{L}$ samples were prepared by the addition of $5 \mathrm{X}$ reducing loading dye to $16 \mu \mathrm{L}$ of each fraction (lanes 1-7). Samples were boiled for two minutes prior to loading. Lane 1 contained a Pink Plus Protein Ladder from BioRad. The gel was stained with Coomassie Brilliant Blue for 10 minutes, and destained with $2 \%$ methanol and $1 \%$ acetic acid. The fractions that clearly contained over-expressed $21.5-\mathrm{kDa} \mathrm{MBP}$, within the range represented by lanes 3 through 6 , were collected for dialysis and further purification.

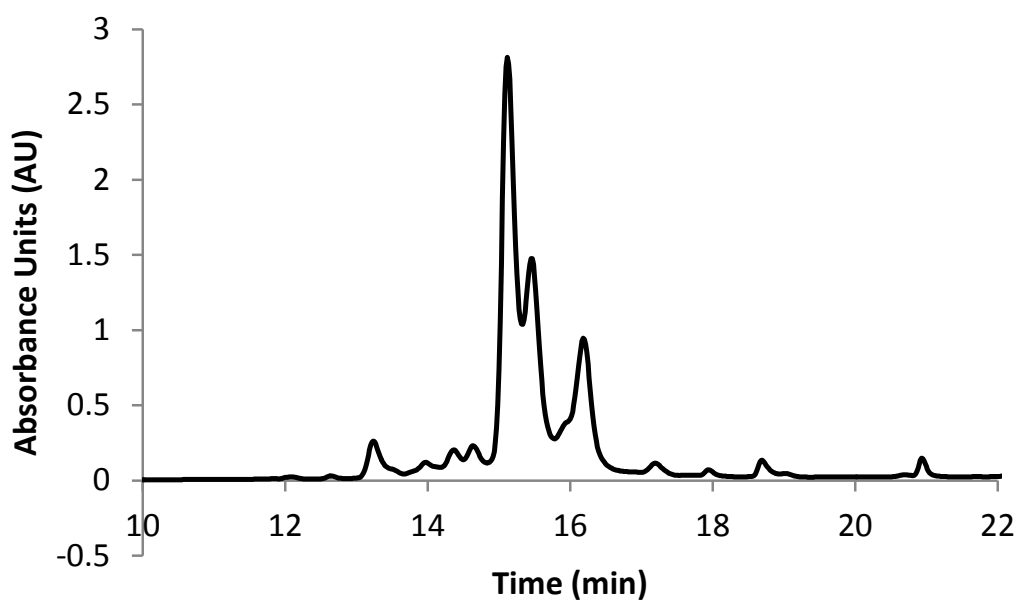

Figure S3. An HPLC chromatogram for analysis of purity of 21.5-kDa MBP purified by cation-exchange chromatography. The mobile phase consisted of acetonitrile, and the ion-pairing agent was $0.1 \%$ TFA. Detection was performed at $214 \mathrm{~nm}$ and $280 \mathrm{~nm}$ (data not shown). The elution gradient began at $75 \%$ sterile water $+0.1 \%$ TFA and $25 \%$ acetonitrile and $0.1 \%$ TFA. Acetonitrile $+0.1 \%$ TFA was increased to $40 \%$ over 15 minutes at $1 \%$ per minute. It was then increased further to $100 \%$ over 2 minutes. The peak occurring at $\sim 15.00$ minutes corresponds to $21.5-\mathrm{kDa}$ MBP monomers, and the peak at $\sim 15.50$ minutes corresponds to $21.5-\mathrm{kDa}$ MBP dimers. The dialyzed cation-exchange fractions were further purified using HPLC chromatography. 